\title{
Sistem Informasi Inventory Dalam Mengolah Bahan Kayu Menjadi Produk Kusen di PB. Mekar Laksana
}

\author{
Ade Mubarok ${ }^{1}$, Chairil M Noor ${ }^{2}$, Bambang Sukajie ${ }^{3}$ \\ 1,2,3 Universitas BSI \\ email: ${ }^{1}$ job.dosen@gmail.com, ${ }^{2}$ chairil.noor@yahoo.com, ${ }^{3}$ b_s_ajie@yahoo.com
}

\begin{abstract}
Abstrak
Sistem inventory merupakan suatu sistem untuk mengetahui persediaan stok barang pada suatu tempat. Sistem inventori sudah banyak digunakan atau dikembangkan pada suatu tempat dengan berbagai macam teknologi dan sistem. Permasalahan pada PB.Mekar Laksana ini adalah belum tersedianya sistem inventori barang sehingga belum bisa mengontrol stok barang yang tersedia. Oleh karena itu, pada penelitian ini akan di bangun sistem informasi suatu sistem inventori yang berbasis web, sehingga informasi tentang stok barang dapat diketahui secara jelas dan terperinci. Sistem inventori barang ini akan diterapkan menggunakan sistem online berbasis web, yang memungkinkan sistem informasi inventori ini dapat diakses melalui internet. sehingga sistem inventori barang dapat dicek atau dilihat oleh suplier sebagai user di sistem tersebut baik melalui web. Metode pengembangan sistem pada aplikasi ini menggunakan metode waterfall yang terdiri dari lima tahapan. Adapun tahapan tersebut yaitu Analisis dan kebutuhan Sistem, desain, Code Generation, testing,support. Aplikasi ini dibangun dengan menggunakan bahasa pemrograman PHP, DataBase MySQL. Serta menggunakan software pendukung Adobe photoshop cs sebagai desain interface. Sistem inventori ini dapat dimanfaatkan dengan beberapa fasilitas yang disediakan yaitu melalui web .Berdasarkan konsep dan perancangan, dapat disimpulkan telah dibangun "Sistem informasi inventory pengolahan bahan baku kayu menjadi produk kusen di PB.Mekar Laksana" untuk membantu admin, manajer dan suplier dalam sistem inventory. Dalam aplikasi ini Manajer dapat mengetahui data barang, data barang masuk, data barang keluar dan suplier yang ingin mengetahui stok barang suplier tersebut. Admin, manajemen dan suplier dapat berinteraksi dengan aplikasi ini sesuai dengan informasi yang dibutuhkan melalui menu yang tersedia
\end{abstract}

Kata Kunci: Sistem Informasi Inventory

\begin{abstract}
Inventory system is a system to find out inventory of goods at a place. Inventory systems have been widely used or developed in a place with a variety of technologies and systems. The problem with PB. Bloom Laksana is the unavailability of an inventory system so that it cannot control the stock of available goods. Therefore, in this thesis will be built an information system for a web-based inventory system, so that information about the stock can be known clearly and in detail. This inventory system will be implemented using a web-based online system, which allows this inventory information system to be accessed via the internet. so the inventory system can be checked or seen by the supplier as a user on the system both through the web. The system development method in this application uses the waterfall method which consists of five stages. The stages are Analysis and needs of Systems, design, Code Generation, testing, support. This application is built using the PHP programming language, MySQL DataBase. And using Adobe Photoshop CS supporting software as an interface design. This inventory system can be utilized with several facilities provided, namely through the web. Based on the concept and design, it can be concluded that it has been built "Inventory information system for processing wood raw materials into frame products in PB. Bloom Laksana" to help administrators, managers and suppliers in inventory systems. In this application the Manager can find out the data of goods, incoming goods data, outgoing item data and suppliers who want to know the stock of the supplier's goods. Admin, management and suppliers can interact with this application according to the information needed through the available menu.
\end{abstract}

Keywords: Inventory Information System 


\section{Pendahuluan}

Kayu merupakan salah satu komoditas utama di dunia, khususnya di Indonesia yang merupakan salah satu Negara penghasil kayu terbesar baik bahan Kayu atau pun produk kayu jadi (kusen).kayu juga berperan sebagai bahan baku dalam pembangunan yang berasal dari alam.Indonesia beruntung mempunyai hutan tropis yang sangat luas,adi ketersediaan kayu sangat banyak.Kayu jati merupakan komoditas yang paling banyak sukai oleh masyarakat,begitu pula kayu alba yg bisa dikatakan dua kayu tersebut merupakan yang paling favorit.

Inventory dalam bahasa Indonesia berarti persediaan. Sedangkan sistem inventory memiliki makna pengaturan persediaan dan berkaitan dengan aktivitas logistik sebuah perusahaan. Di mana kegiatan dari sistem tersebut termasuk dalam pengecekan dan penyediaan stok bahan baku atau barang setengah jadi ataupun barang jadi, demi kelancaran proses produksi atau pemenuhan permintaan pelanggan.

Sistem inventory berguna untuk menentukan jumlah persediaan yang optimal dengan biaya total yang minimal. Persediaan atau inventory meliputi bahan mentah atau bahan baku, bahan pembantu, bahan dalam proses atau work in process, suku cadang, dan barang jadi atau finished good, karena timbulnya ketidakpastian permintaan, ketidakpastian pasokan supplier, dan ketidakpastian waktu pemesanan. Menurut (Utami, 2018)

persediaan (inventory) adalah sebagai berikut "persediaan merupakan bahanbahan,bagian yang disediakan,dan bahanbahan dalam proses yang terdapat dalam perusahaan untuk proses produksi,serta barang-barang adi atau produksi yang disediakan untuk memenuhi pemintaan dai konsumen atau pelanggan setiap waktu".

Salah satu perusahaan yang bergerak dalam bisnis pengolahan kayu adalah PB.Mekar Laksana. Salah satu bagian yang ada di perusahaan adalah permasalahan inventory,dimana ketidaksamaan stok bahan baku yang tersedia dengan data perusahaan. Kemudian tidak efisiennya waktu dalam pencatatan transaksi. Dengan adanya permasalahan yang dihadapi bagian inventory di PB.Mekar Laksana maka diusulkan pembuatan aplikasi berbasis web dimana untuk data inventory dapat diakses bukan hanya secara offline saja melainkan juga secara online.

Sistem merupakan jaringan dari elemenelemen yang saling berhubungan, membentuk suatu kesatuan untuk melaksanakan suatu tujuan pokok dari sistem tersebut. Tujuan pokok dari sistem komputer adalah mengolah data untuk menghasilkan informasi. Sistem yang dimaksud disini adalah sistem yang terotomatisasi, yang merupakan bagian dari sistem manusia dan berinteraksi atau dikontrol oleh satu atau lebih komputer sebagai bagian dari sistem yang digunakan (Kadir, 2003).

\section{Metode Penelitian}

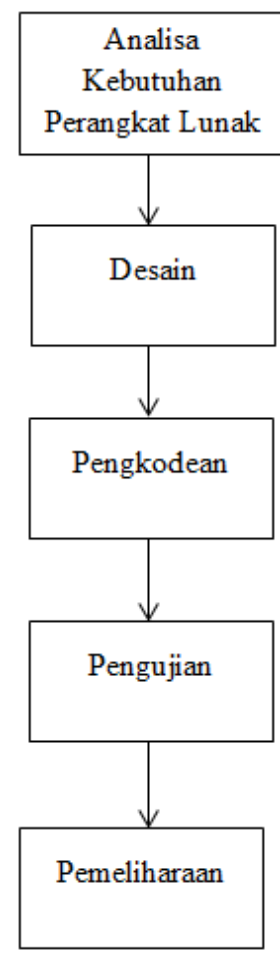

Sumber : Hasil Penelitian

Gambar 1. Metode Penelitian

a. Analisis Kebutuhan Sistem

Melakukan identifikasi terhadap apa yang diperlukan dalam perancangan sistem informasi dan inventory kusen yang berkaitan dengan fungsi tentang proses bagaimana aplikasi berbasis web ini akan menampilkan informasi kepada pengguna agar dalam proses pemesanan berjalan dengan baik, dan interface yang akan digunakan.

b. Desain

Mendesin keseluruhan sistem informasi dan inventory kedalam bentuk Entity 
Relationship Diagram(ERD), Unified Modeling Language (UML), spesifikasi data dan penulis merancang sistem informasi dan inventoy kusen berbasis web dengan menggunakan Macromedia Dreamweaver 8.

c. Code Generation

Tahapan ini merupakan proses pengembangan dari tahap desain ke bahasa pemrograman. Disini penulis menggunakan aplikasi Adobe Dreamweaver CS5 dan MySQL sebagai basis data.

d. Testing

Tahapan ini adalah proses uji coba program yang telah dibuat serta menganalisa hasil dari tahap uji coba tersebut, sehingga website tersebut layak digunakan,

e. Support

Tahapan terakhir adalah support yaitu mengecek kembali program yang telah dibuat, karena tidak menutup kemungkinan ada perubahan yang terjadi karena kesalahan saat tahapan pengujian karena tidak terdeteksi kesalahannya.

\section{Hasil dan Pembahasan}

PB.Mekar Laksana merupakan sebuah perusahaan yang melayani pembuatan \& penjualan kusen kayu kusen. Dimana dalam perusahaan ini berbagai olahan kayu kusen siap jadi dijual kepada masyarakat. Bahan baku kayu yang dipakai di PB.Mekar Laksana yaitu kayu alba,maglied dal lain-lain. Dimana kayu tersebut merupakan kayu dengan kualitas yang sangat bagus.

PB.Mekar Laksana memproduksi berbagai jenis kayu kusen diantaranya produk jendela dan pintu. Dengan kualitas bahan baku yang terjamin juga harga yang pas. Dengan kualitas yang dimiliki PB.Mekar Laksana menjadikan perusahaan ini menjadi sebuah perusahaan yang besar dan banyak diminati oleh masyarakatPada analisis prosedur ini, harus diketahui prosedur yang sedang berjalan untuk perancangan sistem yang baru. Harus diketahui pula hal-hal yang menjadi tujuan pemakai sehingga masalah tersebut dapat didefinisikan secara jelas.

PB.Mekar Laksana adalah perusahaan yang bergerak dalam bidang penjualan. Dalam kegiatan penjualannya, diawali ketika konsumen melakukan pemesanan barang,kemudian informasi pemesanan tersebut akan diteruskan ke bagian admin. Bagian admin juga akan mengirimkan nota pemesanan kepada bagian gudang,kemudian bagian gudang mengerjakan pemesanan kusen yang dipesan konsumen.setelah itu Transaksi penjualan akan dianggap selesai jika bagian keuangan telah menerima pembayaran dan barang telah dikirim.

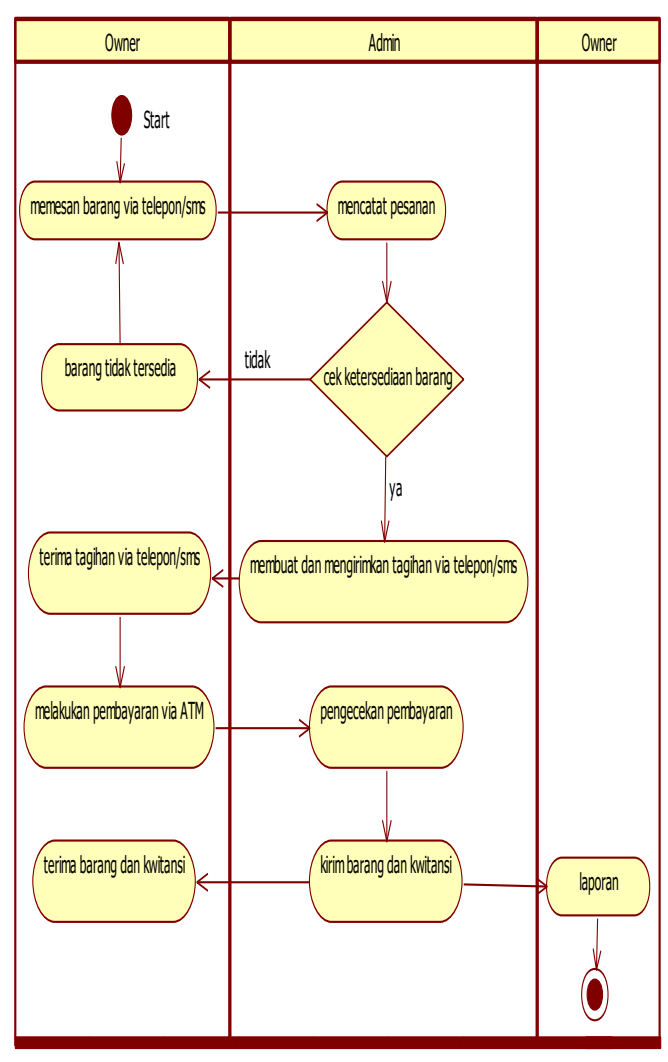

Sumber : Hasil Penelitian

Gambar 2. Activity Diagram

Hasil dari penelitian ini berupa sebuah aplikasi sistem informasi persediaan barang yang dibangun menggunakan perangkat lunak Sublime dan database MySql, serta Adapun kelas-kelas yang terbentuk dari basis data yang dibuat dijabarkan pada entity relationship diagram sebagai berikut: 


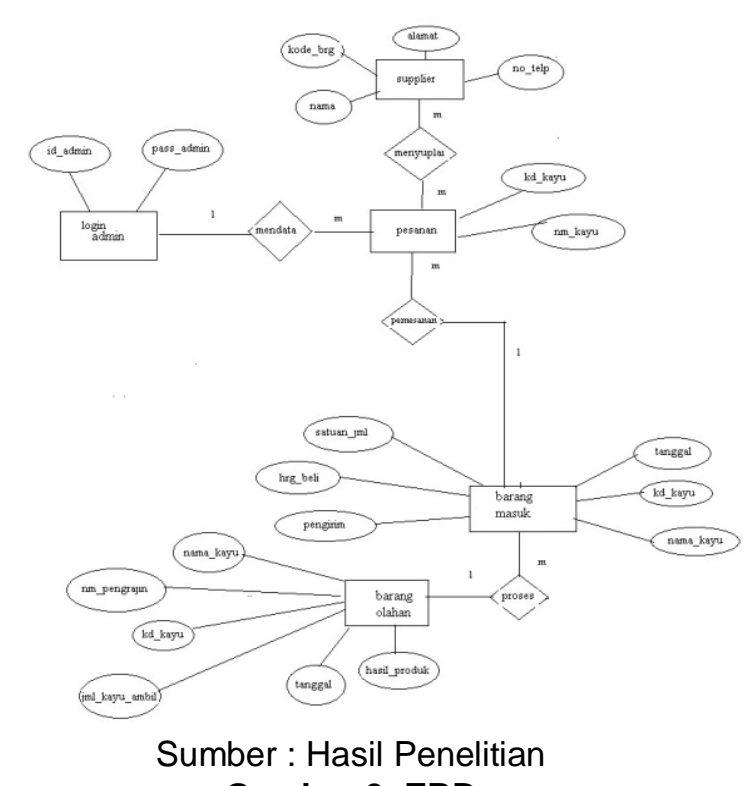

Gambar 3. ERD

Dalam mengimplementasikan hasil program, digunakan user interface dengan hasil tampilannya dijabarkan sebagai berikut:

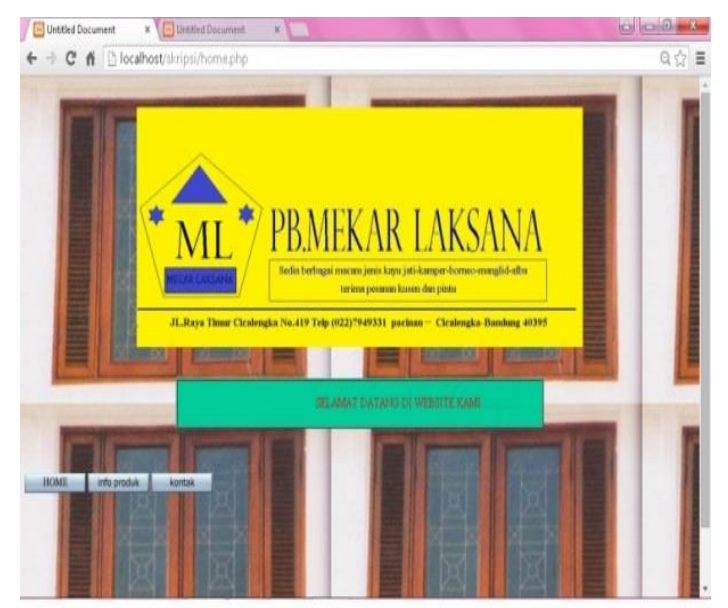

Sumber : Hasil Penelitian

Gambar 4. Tampilan Antar Muka

\section{Kesimpulan}

Beberapa kesimpulan yang dapat diambil dari PB.MEKAR LAKSANA dan penerapan sistem terhadap permasalahan yanag ada dalam perancangan sistem informasi inventory dalam mengolah bahan baku kayu menjadi produk kusen di PB.MEKAR LAKSANA adalah sebagai berikut : a. Konsumen dapat melihat home page perusahaan,dimana halaman ini berisi info-info dari perusahaan mulai dari harga produk kontak perusahaan yang bisa dihubungi.

b. Perancangan sistem informasi inventory pada PB.MEKAR LAKSANA dapat memberikan solusi terhadap permasalahan yang dihadapi oleh PB.MEKAR LAKSANA dalam proses mengelola data-data barang yang ada.

c. Dilakukannya pengujian sistem informasi inventory pada PB.MEKAR LAKSANA diharapkan sistem dapat berjalan sesuai dengan yang diharapkan

\section{Referensi}

Dwiprastio, Chandra \& Karismariyanti Magdalena,ST.MBA (2013). APLIKASI PENJUALAN DAN PERSEDIAAN BARANG DAGANG DENGAN METODE PERPETUAL FIFO BERBASIS WEB (Studi Kasus Pada PD ANUGERAH.

David. Vebriandi, yazed.Auria ,Rizka (2014). Sistem informasi penjualan kayu olahan berbasis website pada CV.Ayad Jaya .STIMIK MDP.Palembang

Kristinugraini, Rina \& Rubhyanti Rini (2014).Jurnal Skripsi sistem Informasi Inventory obat menggunakan metode Fifo pada apotik Mugi Waras berbasis clien server.Semarang

Lamidja, anastasia (2014). Analisa persediaaan bahan baku kedelai pada Agroindustri produk susu kedelai dan tahu cina di Taas banjer studi kasus di UD.kembang tahu. Universitas Sam Ratulangi Manado

Priyadi (2012). Sistem informasi berbasis web pada Smk Muda Patria Kalasan.Amikom.Yogyakarta

Ristono (2009) persediaan dapat diartikan sebagaibarang-barang yang disimpan, untuk digunakan atau dijual pada masa atau periode yang akan datang.

Sahupala, Yeny(2013). Sistem Informasi Inventory Dede's Swalayan 
berbasis web. Sekolah Tinggi Manajemen Informatika dan Komputer El Rrahma.Yogyakarta

Setiawan, Herman(2005). Perancangan Sistem Informasi Inventory PT. Rugo Putra Perdana. Universitas Tarumanagara.Jakarta.

Suwidratis, Driya (2001). Analisa efesiensi sistem pengadaan bahan baku pada industri mebeul skala kecil studi kasus di Koperasi Serba Usaha sekar jati.Tegal

Utami, N. W. (2018, April 10). Mengenal Sistem Inventory \& Cara Mudah Pengelolaannya. Retrieved from www.jurnal.id:

https://www.jurnal.id/id/blog/author/n ovia-widya-utami/ 